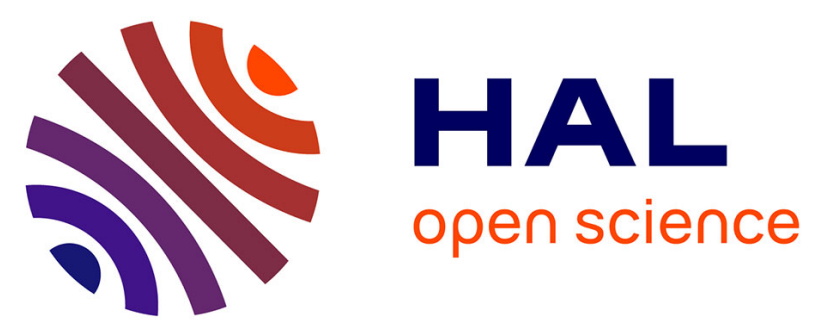

\title{
Probing connections between deep earth and surface processes in a land-locked ocean basin transformed into a giant saline basin: The Mediterranean GOLD project\#
}

Marina Rabineau, S Cloetingh, J Kuroda, D Aslanian, A Droxler, Christian

Gorini, D Garcia-Castellanos, A Moscariello, Evgenii Burov, F Sierro, et al.

\section{To cite this version:}

Marina Rabineau, S Cloetingh, J Kuroda, D Aslanian, A Droxler, et al.. Probing connections between deep earth and surface processes in a land-locked ocean basin transformed into a giant saline basin: The Mediterranean GOLD project\#. Marine and Petroleum Geology, 2015, pp.6-17. 10.1016/j.marpetgeo.2015.03.018 . insu-01197393

\section{HAL Id: insu-01197393 \\ https://hal-insu.archives-ouvertes.fr/insu-01197393}

Submitted on 15 Sep 2015

HAL is a multi-disciplinary open access archive for the deposit and dissemination of scientific research documents, whether they are published or not. The documents may come from teaching and research institutions in France or abroad, or from public or private research centers.
L'archive ouverte pluridisciplinaire HAL, est destinée au dépôt et à la diffusion de documents scientifiques de niveau recherche, publiés ou non, émanant des établissements d'enseignement et de recherche français ou étrangers, des laboratoires publics ou privés. 


\title{
Probing connections between deep earth and surface processes
}

\section{in a land-locked ocean basin transformed into a giant saline basin:}

\section{the Mediterranean GOLD project ${ }^{*}$}

\author{
M. Rabineau ${ }^{1, *}$, S. Cloetingh ${ }^{2}$, J. Kuroda ${ }^{3}$, D. Aslanian ${ }^{4}$, A Droxler $^{5}$, C. Gorini ${ }^{6}$, D. Garcia-

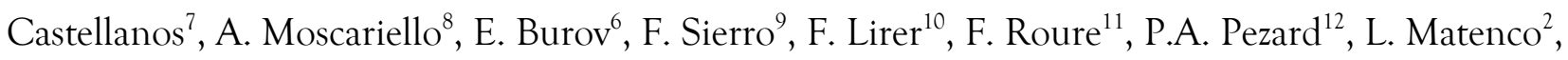 \\ Y. Hello ${ }^{13}$, Y. Mart $^{14}$, A. Camerlenghi ${ }^{15}$, A. Tripati ${ }^{1,4,16}$ and the GOLD $^{\#}$ and DREAM ${ }^{\#}$ Working \\ Groups
}

${ }^{*}$ Corresponding author

1 CNRS, UMR6538, Domaines Océaniques, IUEM, 29280 Plouzané, France

2 Dept. of Earth Sciences, Utrecht University, Budapestlaan 4, 3584CD Utrecht, The Netherlands

3 Japan Agency for Marine-Earth Science and Technology, 2-15 Natsushima-Cho, Yokosuka-city, Kanagawa 237-0061, Japan 4 IFREMER, UR Géosciences Marines, BP 70, 29280 Plouzané, France

5 Department of Earth Science | Rice University MS-126 | 6100 Main Street | Houston, Texas 77005 USA

6 Sorbonne Universités, UPMC, Univ. Paris 06, UMR 7193, Institut des Sciences de la Terre de Paris (iSTeP), F75005, Paris, France

7 Instituto de Ciencias de la Tierra Jaume Almera (ICTJA-CSIC), Solé i Sabarís s/n, 08028 Barcelona, Spain

8 Earth and Environmental Sciences, University of Geneva, Rue des Maraichers 13, CH-1205 Geneva, Switzerland

9 University of Salamanca, Faculty of Science, Plaza de la Merced s/n, 37008 Salamanca, Spain

10 Istituto Ambiente Marino Costiero (IAMC)-CNR Calata Porta di Massa, interno Porto di Napoli 80133, Napoli Italy 11 IFP-Energies Nouvelles, 4 Avenue du Bois Préau, 92852 Rueil-Malmaison

12 Geosciences Montpellier, CNRS, CC60, Univ. Montpellier 2, Pl. Bataillon, 34095, Montpellier, Cedex 5, France

13 Geoazur, 250, rue Albert Einstein, 06560 Sophia Antipolis, France

14 Univ. Haifa, Mount Carmel, Haifa 31905, Israel

15 OGS Istituto Nazionale di Oceanografia e di Geofisica Sperimentale, Borgo Grotta Gigante 42/C, 34010 Sgonico, Trieste, Italy

16 Department of Earth, Planetary, and Space Sciences | Department of Atmospheric and Oceanic Sciences | Institute of the Environment and Sustainability, UCLA, 595 Charles Young Drive, Los Angeles, CA 90095 USA

\section{Abstract}

During the last decade, the interaction of deep processes in the lithosphere and mantle with surface processes (erosion, climate, sea-level, subsidence, glacio-isostatic readjustment) has been the subject of heated discussion. The use of a multidisciplinary approach linking geology, geophysics, geodesy, modelling, and geotechnology has led to the awareness of coupled deep 
and surface processes. Deep earth dynamics (topography, erosion, tectonics) are strongly connected to natural hazards such as earthquakes, landslides, and tsunamis; sedimentary mass transfers have important consequences on isostatic movements and on georesources, geothermal energy repartitions. The ability to read and understand the link between deep Earth dynamics and surface processes has therefore important societal impacts. Ground-truthing at carefully-selected sites of investigation are imperative to better understand these connections.

Due to its youth (<30 Ma) and its subsidence history, the almost land-locked Gulf of LionSardinia continental margins system provides a unique record of sedimentary deposition from the Miocene to present. Due to its high subsidence rate, palaeoclimatic variations, tectonic events and vertical evolution are all recorded here at very high resolution. The late Miocene isolation and desiccation of the Mediterranean, the youngest and most catastrophic event, the Messinian Salinity Crisis (MSC), induced drastic changes in marine environments: widespread deposition of evaporite (gypsum, anhydrite and halite) in the central basin, and intense subaerial erosion along its periphery. These extraordinary mass transfers from land to sea induced strong isostatic re-adjustments that are archived in the sedimentary record and represent a window to the lithospheric rheology and the deep processes.

The GOLD (Gulf of Lion Drilling) project, proposes to explore this unique sedimentary record as well as the nature of the deep crustal structure, providing valuable information about the mechanisms underlying vertical motions in basins and their margins.

\section{Highlights:}

- Characterization of the thermal, petrophysical and mechanical properties of the crust

- Focus on the palaeoenvironment, palaeobathymetry, chronology of early Miocene sedimentation to lower Pliocene 
- Quantification of the consequences of the Messinian event with Thermo-mechanical models

- History of water exchange between the Mediterranean Sea and the North Atlantic

- Limits of life

\section{Keywords :}

Deep drilling, Geodynamics, Passive Margins, Paleoclimate, Messinian Erosional and Salinity Crisis, Deep Biosphere, Georessources

\section{Acronyms :}

GOLD : Gulf of Lion Drilling

DREAM: Deep-sea REcord of mediterrAnean Messinian events

MSC : Messinian Salinity Crisis

IODP : Integrated Ocean Drilling Program

ICDP : International Continental Drilling Program

MDP : Multiple Drilling Program

EPOS: European Plate Observing System

CURVE: Coring a foreland basin: Upper Rhône Valley Events

AMED-1: Actions-Marges Mediteranee-1 cruise

GLWS : Gulf of Lion-West Sardinia Margin System

LWD : Logging while Drilling

BOP: Blow Out Preventer

JAMSTEC : Japan Agency for Marine-Earth Science and Technology

CDEX : Center For Deep Earth Exploration

GR or SGR : Total Gamma Ray

RHOB : density

NPHI : Neutron Porosity

Pef : Photoelectric Factor

NGS : Natural Gamma Ray

CGR : Compensated Gamma Ray

PCATS : Pressure Core Analysis and Transfer System

MDT : Modular Formation Dynamic Tester

QEMSCAN : Quantitative Evaluation Of Minerals By Scanning Electron Microscopy

VSP: Vertical Seismic Profile

S.W.T: Side Wall Cores

\section{Introduction}

One of the critical developments in Earth Science over the past decade has been the recognition of the importance of links between deep Earth dynamics and surface geologic processes (e.g. Cloetingh et al., 2007). The field of dynamic topography has expanded as a 
consequence, but at the same time it has been demonstrated that the outcome of models depends critically on constraints regarding crustal structure and the thermo-mechanical properties of the lithosphere. Since the classical models of McKenzie (1978) and Wernicke (1985), understanding how passive continental margins form, i.e., the thinning of the continental lithosphere leading to vertical movements (subsidence) and its connection with the first oceanic crust, remains a major challenge in Earth Sciences (e.g. Lavier \& Manatschal, 2006; Aslanian et al., 2009; Cloetingh et al., 2013). Deep earth dynamics (topography, erosion and tectonics) are also strongly connected to naturals hazards such as earthquakes, landslides, and tsunamis (e.g. Camerlenghi et al., 2009, Lafuerza et al., 2012). On the other hands, sedimentary mass transfers also have important consequences on isostatic movements (Allen \& Allen, 1990; 2005) and represents a window to the lithospheric rheology and the deep processes (Leroux et al., 2015). These sediment fluxes are the product of erosion and movement of material in and from sources (mountains), the transport by river systems to the plains, and deposition and storage in sink zones. They need to be quantified and modelled in a complete system in relation to the controlling parameters that link temporal and spatial scales across multiple orogen and basin systems (e.g., Matenco and Andriessen, 2013). Sediment deposition and mass transfers have also important obvious consequences on georesources (potential sources, reservoirs and cap rocks quality), geothermal energy (linked to the type of material at depth and burial depth reached) and migration of the fluids. Surely, these results would serve as an invaluable tool for also understanding petroleum systems in relation to the MSC.

Due to its youth and history of strong subsidence, this almost land-locked continental Gulf of Lions-West Sardinia margins system (GLWS) provides a unique record of sedimentary deposition from the Miocene to present that records palaeoclimatic variations and tectonic 
events (including subsidence history). The late Miocene isolation and desiccation of the Mediterranean, a major and extreme event in the Neogene, known as the Messinian Salinity Crisis (MSC), caused massive erosion of surrounding margins and widespread deposition of evaporites in the deep marine basins of Mediterranean Sea (see the consensus synthesis CIESM, 2008) that were only sampled for its uppermost part by IODP drillings during Leg 13 (Hsü et al., 1973) (Fig. 1). These extraordinary mass transfers from land to sea, with up to $1.3 \mathrm{~km}$ of erosion on the shelf (Bache et al., 2009) induced strong isostatic re-adjustments that are archived in the sedimentary record (Rabineau et al., 2014).

Having the advantage of the multidisciplinary academic-industrial Action Marges Program (http://actionsmarges.fr/) and several European projects (e.g. Promess, Euromargins, TopoEurope), the Western Mediterranean Sea, and more specifically the Liguro-Provençal Basin, has been intensely studied from land to deep basin and from surface to deep crustal structure. Various numerical models have been developed to characterize and test « surface " observations (e.g. Dionisos : Rabineau et al., 2005; Rabineau et al., 2006; Leroux et al., 2014; Leroux et al., in press ; Braun et al., 2014); other models focused on modeling the coupling of surface and deep processes (e.g. Burov, E., Poliakov, A., 2001; Koptev et al, 2015, see also the review by Burov E., 2007 ; Cloetingh et al., 2013). The GOLD drilling project proposes a complementary process-oriented and ground-truthed approach, with the objective to better understand and quantify the mechanisms underlying the strong motions in the basin and onand off-shore along the margins trough the sedimentary record, palaeo-environmental evolution and deep crustal structure with the overarching objective to answer the question: what are the mechanisms underlying vertical motions inside basins and their margins?

The GOLD drilling project (Pre-857A) is an integral part of the umbrella IODP project "Uncovering a salt giant" (MDP 857, Camerlenghi et al., 2014), which proposes to carry out 
drilling transects using a set of IODP and ICDP platforms, extending from the basin margins to the deep ocean basins, and linking sediment source to sink (Fig. 2). These projects aim to settle the dispute about the desiccation history of the Western Mediterranean Sea by recovering a complete MSC sequence. In that view, the GOLD drilling project is end-member of the scientific drilling initiative 'Uncovering a Salt Giant' which encompasses scientific objectives focussed on the MSC (Deep-sea Record of Mediterranean Messinian Events (DREAM)) (Fig. 2). GOLD shares these objectives and others related to the deep crustal processes, deep biosphere, deformation and fluid flow.

\section{The Gulf of Lion-Sardinia margins system: a Unique Natural laboratory}

The Gulf of Lion-West Sardinia margins system (GLWS) corresponds to a pair of rifted margins formed by the rupture of the Corso-Sardinian micro-continent from the IberoEuropean plate since Priabonian time (33.7Ma - Réhault et al., 1984) in the context of collision between the African and European plates (Cloetingh and Kooi, 1992; Olivet, 1996). The opening took place at the southern end of the intra-European rift system, in a back-arc situation and in response to a SE rollback of the slab of the African plate subducting beneath the Maghrebides-Calabrian-Apenninic arc during an extensional phase (Kooi et al., 1992; Réhault et al., 1984; Jolivet \& Facenna, 2000). The Corso-Sardinian microcontinent's counterclockwise rotation resulted in the emplacement of an oceanic crust starting in the late Aquitanian (23Ma to 19Ma) and lasting until the Langhian (around $15 \mathrm{Ma}$ ) (Olivet, 1996). Although the geodynamic evolution of rifting in back-arc basins is different when compared with cratonic rifting, the mechanics of thinning of the continental crust is rather similar (Aslanian et al., 2012; Cloetingh et al., 2013). The Sardinia Cruise (2006) surveyed both conjugate margins (Gailler et al., 2009; Moulin et al., in press; Afilhado et al., in press), allowing precise palinspastic reconstruction of the Gulf of Lion - Sardinia margins system (GLWS) showing the 
same configuration as those of Atlantic margins and intracontinental basins (Aslanian et al., 2013). Moreover, the puzzling similarity in the seismic velocity profiles of the intermediate domain and the atypical oceanic crust (Moulin et al., 2015; Afilhado et al., 2015) questions the role of the lower continental crust in the first oceanic crust fabric, as proposed Aslanian et al. (2009) and Sibuet et al. (2012) following the earlier proposition of Bott (1971). The Gulf of Lion-Sardinia margins system is expected to have a continuous and relatively complete sedimentary series, neither affected by basement tectonics nor by recent tectonic or gravity processes, and that can be divided in two second-order sequences: a late Aquitanian/Burdigalian transgressive sequence with a mixed silicoclastic-carbonate platform in a ramp-like configuration (Gorini, 1993), and a Langhian-Tortonian sequence characterised by prograding clinoforms on the platform and turbidites in the deep basin. During this last timeinterval, major palaeogeographical change occurred with the initiation of the Rhône River and the creation of a platform-slope-basin morphology.

\section{GOLD: Understanding the extreme Messinian Salinity Crisis (MSC) event and the} deep response of the lithosphere.

The MSC is the youngest and most catastrophic event to occur during the Neogene period, inducing drastic changes in marine environments, widespread deposition of evaporite (gypsum, anhydrite, and halite) in the central Mediterranean basins (Hsü et al., 1973), and intense subaerial erosion along its periphery (Clauzon, 1973). The closure of the Mediterranean is believed to be linked to uplifts of the Rifean Corridor and/or Betic internal basins due to slab detachment, with an uplift of more than $1 \mathrm{~mm} / \mathrm{yr}$ indicated over a period of at least $80 \mathrm{ka}$ (Garcia-Castellanos and Villaseñor, 2011) but may also be connected to the major worldwide Neogene kinematic change at the end of chron C3a ( 5,9 My), clearly imprinted for instance 
on the Pitman FZ (Cande et al., 1995) and in the Pacific-Antarctic ridge area (Géli et al., 1997; Ondreas et al., 2001). In the Western Mediterranean, this event has a well-preserved record. A variety of different interpretations have been proposed for MSC-related deposition and reflooding, each with their own strong palaeoenvironmental, tectonic, isostatic, and climatic implications, thus emphasizing the need to drill the entire sedimentary section in the deep basin:

(1) Interpreted thickness ranges from a "minimal" estimate with thin chaotic detritics $(1 \mathrm{~km})$ coeval with evaporite deposition and with additional turbiditic components embedded in the Lower Unit (Lofi et al., 2011), to a "maximal" estimate with huge, thick, fan detritics deposited prior to the Lower Unit (Bache et al., 2009), mixed with evaporites (Gorini et al., 2015) for a total thickness of $3.5 \mathrm{~km}$.

(2) The re-flooding is generally seen as a rapid flood along the strait of Gibraltar. It has been suggested that the re-connection itself was caused by subsidence to a threshold below the level of the Atlantic, by faulting, by erosion, or by a combination of these three mechanisms (Loget et al., 2005; Garcia-Castellanos et al., 2009). Geomorphological evidence from the strait suggests a large, catastrophic discharge (Blanc, 2002). Numerical modeling shows that the feedback between the rate of water inflow and the erosion it exerts on the gateway could run at a relative low water discharge for as much a few thousand years. Seismic stratigraphy shows a prominent flat wave-cut surface interpreted as erosional features carved during the refill, which argues for a slow initiation of the refill (Bache et al., 2009). However, to explain the prominent erosional trough observed in the Alboran Sea (a feature that is revealed by seismic stratigraphy as deeper than 300 $\mathrm{m}$, wider than $6 \mathrm{~km}$ in places, and at least $200 \mathrm{~km}$ long; Estrada et al., 2011), the flood's feedback should eventually lead to a water discharge close to $10^{8} \mathrm{~m}^{3} / \mathrm{s}$, vanishing the 
level difference across the Gibraltar threshold in no more than a few years (GarciaCastellanos et al., 2009). If confirmed, this would consist of the largest documented flood event on Earth, exceeding by a factor of 10 the Missoula and the Altay outburst floods during the Pleistocene.

The large shelf and the low continental slope gradient in the Gulf of Lion offers the best potential for understanding the Messinian Mediterranean event as a whole. Here, we can measure subaerial erosion on the shelf, observe markers of marine transgression on the slope and toe of the slope, and map the succession of detritic units, their lateral seaward evolution, and their correlation with the evaporites. This area is unique in that it provides a full record of evaporite deposition in a deep basin. Its understanding requires an integrated approach quantifying the coupling of geodynamic, and surface processes, and linking IODP-ICDP drillings with transects from the basin margins to the deep ocean basins where the sediment source-to-sink budget is well constrained. A new ICDP project (CURVE) has been submitted in January 2015 in that view (Loget et al., 2015). This will go hand-in-hand with multiscale seismic imaging of basin fill and the crustal and upper mantle structure through a combination of multichannel and wide-angle seismic profiling, and the deployment of novel seismic instrumentation (including the Mermaid system of floating seismometers (Jones, 2014) and the European Plate Observing System (EPOS)). Data will be interpreted with the aid of state-of-theart coupled analogue and numerical facilities and experimental rock-deformation laboratories (e.g. Burov et al., 2001; Burov, 2007; Watremez et al., 2013; Burov and Gerya, 2014; Koptev et al., 2015; Calignano et al., 2015).

An exciting target for stable isotope investigations of the Messinian crisis that we will examine are evaporite minerals including sulfates (such as gypsum, jarosite, and hanksite), as well as halite and sulfohalites. Analysis of these minerals provides a means to determine fluid oxygen 
isotope $\left({ }^{18} \mathrm{O} /{ }^{16} \mathrm{O}\right)$ and hydrogen isotope $(\mathrm{D} / \mathrm{H})$ ratios (Yang et al. 1995; Khademi et al., 1997; Hodell et al, 2012). Therefore mineral fluid inclusions specifically may allow us to reconstruct paleohydrology. Although the composition of waters can be influenced by diagenesis, measurements of both sulfates and halites in co-occurring samples will allow for independent verification of fluid characteristics of co-precipitating mineral phases, to determine the possibility of isotopic signal degradation in a mineral of interest by re-equilibration with exogenous fluids.

Hydrographic conditions will also be constrained using more traditional paleoceanographic proxies, including widely-used carbonate-based proxies such as $\delta^{18} \mathrm{O}$ and $\delta^{13} \mathrm{C}$ in foraminifera (e.g., Rohling, 1999; Turco et al., 2001). Foraminiferal Mg/Ca records may help constrain paleotemperature and to disentangle temperature from water isotope (and salinity) changes, though previous studies have shown in the Mediterranean the presence of high-salinity waters (Ferguson et al., 2008) and carbonate overgrowths (Boussetta et al., 2011) may pose potential challenges in data interpretation. However, the application of methods such as flow-through time-resolved analysis (Hoogakker et al., 2009) and laser-ablation inductively-coupled plasma mass spectrometry (Fhlaithearta et al., 2010) can be used to separate out signatures of primary versus secondary phases in such successions. The recently-developed clumped isotope thermometer represents another potential temperature proxy that will be used (Tripati et al., 2010, 2014; Eagle et al., 2013; Tang et al., 2014).

In addition, reconstruction of the history of water exchange between the Mediterranean Sea and North Atlantic will be attempted based on the isotopic records of $\mathrm{Sr}, \mathrm{Nd}$ and $\mathrm{Pb}$ in iron oxides and fish teeth (Flecker et al., 2002; Flecker and Ellam, 2006; Khelifi et al., 2009) Bromine concentrations and the stable isotopic compositions of sulphide, osmium, chlorine $\left(\delta^{37} \mathrm{Cl}\right)$ and boron $\left(\delta^{11} \mathrm{~B}\right)$ might also be used to further constrain the nature of the original 
water, evaporative and post-depositional processes (e.g. Vengosh et al., 1992; Eggenkamp et al., 2013), and evaporite crystal growth patterns that are controlled by the environment of their formation (Lugli et al., 2010; Van Den Driessche et al., 2011). These measurements will be performed from either core of in-situ fluid samples collected with the Modular Formation Tester (M.D.T.), from which formation pressure and pointwise permeability evaluations might be performed from small scale production tests (a few tens of cc each time). In sections where no core will be taken, miniplugs might be obtained from the SideWall Coring tool (S.W.T.).

\section{GOLD as a key project for understanding connections between deep earth and surface processes}

The almost land-locked Gulf-of Lions - Sardinia continental margins system is a unique natural laboratory to address such key questions on passive margin genesis, the nature of the intermediate crust and the first atypical oceanic crust, the timing of subsidence and its imprint in sedimentary systems, glacio-isostatic rebound, and the impact of the mass transport, in particular during the MSC.

Comprehending thinning of the continental lithosphere leading to vertical movements (subsidence), remains a major challenge in the Earth Sciences. Conservative models, which exclude exchanges between the lower continental crust and upper mantle, are usually proposed to explain the lithospheric stretching and consequential crustal thinning of passive continental margins. Major effort has been made to explore the conjugate Galician/Iberian and Newfoundland margins (ODP Legs 103, 149, 173, 210). Nevertheless, their results mainly concern an end-member of conjugate passive margins with strong continental lower crust (Huismans and Beaumont, 2011) and cannot be applied in general to other margins. Moreover, evidence of an emerged or shallow marine position of margins until the break-up (Aslanian et 
al., 2009; Péron-Pindivic and Manatschal, 2009; Bache et al., 2010), absence of extensional faults (Moulin et al., 2005; Bache et al., 2010; Unternher et al., 2010; Moulin et al., in press) anomalous heat flow (Lucazeau et al., 2010), the presence of a strong reflector in the lower crust (Pascal et al., 1994; Moulin et al., in press) and of exhumed mantle (Boillot et al., 1989), have all modified our concepts of margin formation. The physical and numerical models proposed to explain some of these observations (Burov and Poliakov, 2001; Lavier and Manatschal, 2006; Kuznir and Karner, 2007; Reston, 2010; Huismans and Beaumont, 2011; Munteanu et al., 2014) imply huge horizontal movements, which do not fit the geological and geophysical observations (Aslanian et al., 2009; Aslanian and Moulin, 2012). Comparisons between different conjugate margin systems in different tectonic contexts around the world (Central Atlantic: Labails et al., 2009; South Atlantic: Aslanian et al., 2009; Liguro-Provencal Basin: Moulin et al., in press; Afilhado et al., in press; Black Sea: Munteanu et al., 2011; Pannonian Basin: Matenco and Radivojeviić, 2012), intracontinental basins (Baikal lake: Thybo and Nielsen, 2010; Parentis Basin (Marillier et al., 1988), and aborted rifts (Valencia Basin: Torné et al., 1992) present a similar picture, with a $-200 \mathrm{~km}$ wide thinned basin in high position and missing lower continental crust (Aslanian et al., 2013). The thinning process seems to be depth dependent and to mainly involve the lower/middle crust, which appears to be exhumed in the continent-ocean transition zone (Burov and Poliakov, 2001; Burov, 2007; Watremez et al., 2013 Aslanian et al., 2009; 2013). However, this exhumation does not explain the entire thinning of the system (Aslanian et al., 2009; 2013). The thinning of the continental crust cannot be explained only by stretching, shears, faults or lower crust exhumation; some lower crust is still missing, and must have flowed elsewhere or mixed with the upper mantle (Aslanian and Moulin, 2012). This behaviour of the lower continental crust has strong implications for deep processes, vertical movements, and isostatic response to the mass transfer (e.g., Tesauro et al., 
2011) that should be readable in the sedimentary record. The nature and age of drilled sediments should provide major insight into palaeogeography, fluvial dynamics, palaeobathymetries, sea-level changes, sedimentary fluxes, erosion/sedimentation balance, and subsidence.

In addition, the MSC event was both a time of extreme erosion and major sea-level fall, huge mass transfer and important halite deposition implying major isostatic vertical movements, recently quantified on the outer shelf (Rabineau et al., 2014). The amount of isostatic movement associated with the MSC still needs to be quantified in the deepest basin and related to the nature of the substratum that needs to be sampled and related to the rheology of the underlying material.

Finally, the post-rift subsidence was recently measured by the direct use of sedimentary geometries analysed in 3D and validated by numerical stratigraphic modelling (Leroux, 2012; Leroux et al., 2015, in press). Three domains of subsidence were identified: on the platform and slope, the subsidence takes the form of seaward tilting with different amplitudes, whereas the deep basin subsides purely vertically. These domains agree with the deeper crustal domains highlighted by previous geophysical data (Moulin et al., in press) and that the post-break-up subsidence continues to use the initial hinge lines of the rifting phase. This striking correlation between surface geologic processes and deep earth dynamic processes reveals the sedimentary record and sedimentary markers as a window into deep geodynamic processes, which may be used to decipher the laws of subsidence (Leroux et al., 2015).

The sampling of post- and pre-salt sedimentary layers and crustal material in the key intermediate domain will allow us to test competing ideas about passive margin genesis and subsidence, to validate the interpretation of crustal velocity models, and to quantify the striking correlation between surface and deep earth dynamic processes. 
The GOLD project is key for understanding the geodynamic evolution, structural settings and sedimentological deposition in a large number of analogue natural laboratories in the Mediterranean domain. Similar with the Liguro-Provencal Basin, a large number of other rapid roll-back systems associated with the formation of highly arcuated orogens (Jolivet and Faccenna, 2000; Faccenna et al., 2004) have created similar contrasting extensional back-arc basins with hyper-extended margins floored by oceanic or continental lithosphere and locally inverted, such as the Alboran Domain, Pannonian Basin, Black Sea or Aegean Basin (e.g., Brun and Sokoutis, 2010; Cloetingh et al., 2006; Crespo-Blanc \& Frizon de Lamotte, 2006; Matenco and Radivojevic, 2012; Munteanu et al., 2013). Many of these situations retain similar key elements that make the GOLD drilling site the best area to extrapolate the process-oriented understanding required to analyze features such as hyper-extended crust, rapid prograding environments or extra-ordinary sea-level variations. In particular, the comparison with the MSC events recorded with variable amplitudes along the systems of connected basins with variable paleobathymetries of the Paratethys (e.g., Krijgsman et al., 2010; Leever et al., 2010; Munteanu et al., 2012; Popov et al., 2006; ter Borgh et al., in press), where no significant salt was deposited, is important for discriminating processes related with large sea-level variations from the ones specific to salt deposition.

\section{GOLD and its link with heat and fluid flow processes and the Deep Biosphere}

The heat flow at GOLD position has been measured recently during the AMED-1 cruise (Sept 2013) on a shallow core which revealed a surface heat flow value of $59 \mathrm{~mW} / \mathrm{m} 2$ (pers. comm. J. Poort), taking into account the conductivity of the sampled clay sediments that induce a blanketing effect (Lucazeau and Le Douaran, 1985). This new measurement is similar although slightly lower than that reported earlier $\left(62-64 \mathrm{~mW} / \mathrm{m}^{2}\right.$ in Burrus and Foucher, 1986). 
However, the presence of a thick, heat-conductive salt layer stongly alter the local temperature distribution in the sediments. The geothermal gradient has an inverse relation with the conductivity for the same heat flux, therefore thick salt layers or domes cause higher geothermal gradient and temperatures above the salt and lower geothermal gradient and temperatures below the salt (Bjorlykke, 2010). The drilling will offer a unique opportunity to better estimate the effect of salt layers and anticlines on the thermal field. Moreover, signs of overpressure and fluid escape have been described further South of this area (Carmenlenghi et al., 2009; 2012), which can be another important source of local thermal perturbations in sedimentary basins (e.g. Poort and Klerkx, 2004; Grevemeyer et al., 2004). Particular care will be needed to monitor any overpressure at the GOLD site, and increase mud weight when appropriate in addition to the installation of the BOP. Hence, the drilling will also help to better understand the mechanisms of fluid migrations, including through the salt layer as recently reviewed by Bertoni \& Cartwright, 2015. For this, geochemical analyses of pore water composition will be crucial to help determine the source depth and temperatures, and velocities of the fluids. To collect samples at depth and ensure in-situ conditions are retained at the surface during laboratory measurements, we want to propose deploying specialist tools like PCATS (Pressure Core Analysis and Transfer System : hydrostat pressure, MDT (Modular Formation Dynamic Tester : Pressure and permeability from High res gauges, fow line resistivity) for collecting in-situ fluid samples, mechanical sidewall tools for retrieving minicores / sidewall cores.

GOLD will also address questions concerning the microbial communities and associated environments in extremely deep marine sediments of the Mediterranean Sea. The site severe physico-chemical environment makes it ideally suited to address the habitability of environmental extremes, where high pressure, temperature, and salinity all may constrain the subsurface biosphere in this context. In this regard, GOLD is a unique opportunity to 
investigate the interacting effects of multiple extremes within and between diverse sedimentary strata. Potential microbial communities entombed in hypersaline deeply buried paleoenvironments will be compared to microbial communities that have been described in today's Mediterranean brines (Antunes et al., 2011; Siam et al., 2012; Maignien et al., 2012). These types of subsurface communities should be very distinct from lineages of subsurface sediments of normal salinity (eg. Fry et al., 2008; Teske et al., 2008). The GOLD project will therefore allow a detailed investigations of the effects of temperature, pressure and hypersalinity on: (i) microbial diversity/activity, (ii) life's physico-chemical limits, and (iii) the adaptation of subsurface life to environmental changes before, during, and after the Messinian Salinity Crisis.

\section{Establishing the chronostratigraphy in GOLD project}

The proposed site $\left(\mathrm{N} 41^{\circ} 45.92^{\prime}, \mathrm{E} 05^{\circ} 00.10^{\prime}\right)$ is located at the toe of the continental slope at a water depth of $2420 \mathrm{~m}$ in the distal part of the Rhône deep-sea fan (Droz et al., 2006). A short $3 \mathrm{~m}$ core has recently been acquired at the drill site during the AMED-1 cruise and shows alternating clays and silts. At this site, we aim to drill down to the crust, through the $6230 \mathrm{~m}$ of sediments deposited during the last $-23 \mathrm{Ma}$. This drilling requires the use of a riser drill ship equipped with a Blow Out Preventer to go through the $600 \mathrm{~m}$ thick Messinian halite sequence. This could be done by academia only with the Chikyu drillship from Japan, being the only vessel available within IODP that can satisfy this requirement (see plate 1 ). The succession of strata has never been drilled through before in the deep Western Mediterranean Sea, and the unexplored strata below the salt have never been sampled.

Wire line tools and measurements (Hearst and nelson, 1985; Ellis, 1987) will give us a continuous and high resolution picture of the complete depositional megasequence corresponding to the MSC (Gorini et al., 2015). Increased knowledge of rocks petrophysical parameters and high quality log data (spectral gamma ray data for clay identification, acoustic velocities, electrical resistivity, density and capture cross sections for neutrons and electrons) 
will provide a complete calibration of the deep basin sedimentary sequence and seismic facies. In particular, the knowledge of depositional environments and petrophysical characteristics will provide a complete geologic insight, including relative changes in sea level, sequences and cyclostratigraphy within the deep western Mediterranean basin. These measurements are fundamental in analyzing the MSC deposits and their paleogeographic settings. Drilling a giant saline basin implies specific tools and measurements (Renoux et al., 1991). Evaporitic rocks, carbonates, and clastics sediments are characterized in particular by various densities and capture cross sections data that can be discriminated by the use of nuclear tools (Ellis, 1987) such as the density tool (or LDT, for RHOB and the Pef) and so-called neutron porosity tool (for NPHI and SIGMA). For example, the photo-electric factor (Pef) allows the discrimination between sandstones (2 barns/el), dolomite ( 3 barns/el) and carbonates ( 5 barns/el). Similarly, large differences in Pef and capture cross section values (SIGMA) are obtained for different evaporitic minerals. While the former is directly available from the LDT, the latter is given by the Neutron (NPHI) tool, which allows the discrimination of water bearing minerals such as gypsum (CaSO4,2H2O)-(+50 p.u.) and carnallite ( $\mathrm{KCl} \mathrm{MgCl} 2$,6H2O)-(+60 p.u.). Another important tool for minerals identification is the spectral gamma ray (N.G.T). It records selectively the Thorium (p.p.m.), Potassium (\%) and Uranium (p.p.m.) natural radioactivity. Uranium content being characteristic of the $\mathrm{pH}$ (precipitation under euxinic conditions as for primary dolomites). The thorium log is the best indicator for clay identification. In particular, the thorium-potassium ratio provides a qualitative but clear identification of clay mineralogy. As a consequence and for example, the coupling between potassium and neutron logs leads to a direct determination of Carnallite $(\mathrm{KCl}, \mathrm{MgCl} 2,6 \mathrm{H} 2 \mathrm{O})$. Finally the sonic tool allows the determination of $\mathrm{P}$ and $\mathrm{S}$ velocities at depth $(\mathrm{m} / \mathrm{s})$. This tool might also be a discriminative for some of the matrix components such as anhydrite $(50 \mu \mathrm{s} / \mathrm{ft})$, and halite $(67 \mu \mathrm{s} / \mathrm{ft})$. In addition, the $\mathrm{P}$ and $\mathrm{S}$ velocities allows the computation of mechanical coefficients (such a the bulk and shear modulii, or the Poisson's ratio). Real time sonic-while-drilling acquisition could be essential to monitor to the existence of potential overpressured zones, but would require the use of LWD, which remains an alternative through the salt.

Detailed petrographical analysis performed with the QEMSCAN automated analytical system both on cuttings and core samples coupled with detailed clay mineralogy performed on selected samples at regular intervals throughout the drilled sequences, will allow the pin point key 
changes in composition of the sedimentary sequence and explain wireline log responses. These will provide indication on sediment provenance (heavy minerals), weathering processes and climate affecting the basin margin areas (smectite vs kaolinite vs illite) and diagenetic processes. The latter are important to ascertain the degree of preservation of biostratigraphic component and its significance.

The combination of high-resolution biostratigraphic studies based on Nanofossils, planktonic Foraminifers, and Dinoflagelates, together with magnetostratigraphy and wireline logging cyclostratigraphic patterns will provide an accurate chronostratigraphic framework for the pre- and post-evaporite strata (e.g. Gautier et al., 1994; Krijgsman et al., 1999; Sierro et al., 2001; Flores et al., 2005; Lirer \& Iacarino, 2005; Di Stefano et al., 2008...). Identification of Foraminifer microfosssils in marine Neogene series in the Mediterranean Sea has been successfully carried out in many industrial boreholes in the Valencia Basin, Gulf of Lions (down to more than 4000 mbsf), Cadix and DSDP boreholes despite of their diagenetic imprint (Cravatte et al., 1974; Lanaja et al., 1987; Sierro et al., 2000; Ochoa et al., submitted).

The final goal will be to tune the sediment cycles (if identified in the logs), with astronomical solutions as has been reported in many studies on rhythmic sections onland with an accuracy of a single precession cycle (+/- 20 ka) (e.g. Hilgen et al., 1995; Suc et al., 1995; Sierro et al., 2001; Lirer et al., $2005 ;$...). The same approach has been sucessfully applied to offshore downhole logs with cyclic records (Sierro et al., 2000; Williams et al., 2002; Ochoa et al., submitted). This approach would be very accurate with continuous downhole logs further calibrated using the cores (normal cores and/or lateral cores) but can also be performed with cuttings.

For the MSC interval, classical biostratigraphy will be limited because of the lack of typical open marine microfossils and no magnetic reversal expected within this time period. However, evidences from outcrops and onshore wells show cyclic sedimentation with alternations of 
gypsum and laminated marls with microfossil contents (benthic Foraminifers and Ostracods). These sedimentary sequences give a typical logging signal (Ochoa et al., submitted) that can be used to establish a robust chronology.

At the GOLD site, specific wireline logging tools will also be crucial to recognize patterns and alternating of lithological sequences (see above), to precise through direct pore fluid sampling the nature of in-situ fluids, to get information about hole stability at great depth, to study in particular the deformation of the salt under a steep geothermal gradient, or to determine ahead of time the top and the base of the salt from downhole seismic probing.

Cyclical changes in the logs in combination with microfossils, lithologic and geochemical properties (e.g. Strontium isotopes) of the sediment can be interpreted in terms of paleoenvironmental changes (e.g. Flecker et al., 2006, Sprovieri et al., 2003). Additional independent chronostratigraphic constraints can be provided by radiometric datings of tephras or microtephras, as volcanic activity is reported in nearby regions from the Mediterranean Sea during the messinian period in Murcia (Krijgsman et al., 2006), and in the Tyrrhenian site 654 Leg 107 (Kastens et al., 1987).

Moreover, borehole stability data will be essential to drill to more than $6 \mathrm{~km}$, in particular through the thick salt layers. Data on borehole deformation might be obtained from the two orthogonal calipers of the Formation Micro Scanner (F.M.S.) borehole wall imaging tool (Pezard et al., 1990; 1992), or else with a full description of boreholes sections obtained from acoustic images of the borehole surface (Zemanek et al., 1970; Maury et al., 1999) with the Ultrasonic Borehole Imager (U.B.I.). In either cases, these $\mathrm{cm}$-scale electrical or acoustic images of the borehole surface will provide essential high resolution data about sequence stratigraphy and sedimentological processes. Likewise, for borehole completion and the precise determination of adequate depth to set the different casing strings used to protect the upper 
part of the hole while drilling, Vertical Seismic Profiles (V.S.P.) might be conducted to determine either the top or the base of the salt, both well identified from sesimic profiles (e.g. Lofi et al., 2011).

In all, the GOLD project is divided in two parts (Plate 1): The first part targets more surficial processes and will provide the first chronological, lithological, palaeoenvironmental, palaeooceanographic, and palaeoclimatic constraints from samples in the deep basin through the entire MSC, and will also examine the deep biosphere. The GOLD deep site will provide the unique opportunity to determine how multiple extremes of high temperature, pressure, and salinity impact on life's frontier(s): When does the biosphere truly become the geosphere? The second part (Plate 1) will sample pre-MSC sediments to reconstruct the early history of the basin and its vertical evolution related to deeper processes. We will drill down to the substratum to reach, sample and ground-truth the petrographic nature of this unknown substratum.

As a summary, the main objective of GOLD (Plate 2) is therefore to sample for the first time the deep basin of the Mediterranean Sea in the Gulf of Lion while recovering strata from the base of Pliocene, through the Messinian Series (both detritic and evaporitic strata), the preMSC Series, and down to basement rocks in a key transitional zone of unknown petrographic nature, in order to:

1) Constrain the timing and quantify the consequences of MSC base-level change on river behaviour, the erosion, supply, and transport of sediment, karstification, evaporites deposition and landscape-relief evolution, through the characterization and quantification of sediment fluxes. 
2) Reconstruct a complete history of basin vertical evolution, with specific focus on the palaeoenvironment, palaeobathymetry, and chronology of early Miocene sedimentation, to address fundamental questions about rifting, passive margin genesis, and the nature of the first oceanic crust.

3) Characterize the thermal, petrophysical and mechanical properties of the lithospheric crust underlying the Western Mediterranean and establish the relationship between temporal and spatial variations in crustal structure and the mechanisms that generated the spectacular vertical motions of both the basin and its margins during the MSC.

\section{Conclusion:}

The GOLD project proposes to drill a complete sedimentary column without faults, major erosional hiatuses, or sedimentary time gaps down to the transitional crust in the Western Mediterranean Sea. The selected GOLD site is one of the very few deep target sites that can satisfy 1) technological and security constraints (linked with the use of IODP vessels and specially the R/V Chikyu operated by CDEX-Jamstec, such as: bathymetry <2500 m, bottom hole maximum depth $<9 \mathrm{~km}$ ), 2) scientific constraints, such as low geothermal gradient (for the deep biosphere), absence of salt diapirs (for the preservation of a complete stratigraphic record), and sampling of the transitional crust. The GOLD Project will gather a unique group of expertises. A Public-Private Consortium could be created with representatives from various international universities, public institutions, companies from the petroleum sector and any other industrial technical or environmental sectors.

Acknowledgements : 
Authors are greatful to all members of the GOLD and DREAM working groups, that comprises around hundred researchers. Specific thanks to Guus Nolet, Jeffrey Poort and Francis Lucazeau and Patrick Renoux who provided key information (respectively on Mermaids tools, geothermal gradients, and wireline loggings) and comments on parts of the paper.

This paper greatly benefited from the thorough comments and suggestions of two anonymous reviewers that greatly improved our manuscript.

The work in the Gulf of Lion and long-term drilling project, including offshore cruises, has been supported by CNRS, IFREMER, IFPEN, BRGM, EDROME, IUEM, the french alliance (Allenvi and Ancre), CNFH (Commission National de la Flotte Hauturière Française) and different national and international Programs : Actions Marges, MISTRALS-Termex, Labex Mer (ANR-10-LABX-19), CNRS-INSU SYSTER, CNRS-INSU INTERRVIE, ARTEMIS, MAGELLAN + European Program, TopoEurope and ILP (International Lithosphere Program), RCMNS, IODP-France, ECORD, JSPS, JAMSTEC and CDEX and IODP.

\section{References}

Afilhado, A., Moulin, M., Klingelhoefer, F., Aslanian, D., Schnurle, P., Nouzé, H., Rabineau M., Leroux, E., Beslier, M.O., 2015, in press. Deep crustal structure across an young passive margin from wide-angle and reflection seismic data (The SARDINIA Experiment) II. Sardinia’s margin. Bull. Soc. Géol. France Special Issue.

Antunes, A., D.K. Ngugi and U. Stingl. 2011. Microbiology of the Red Sea (and other) anoxic brine lakes. Environmental Microbiology Reports 3:416-433.

Aslanian, D. Moulin, M., Olivet, J.-L., Unternehr, P., Matias, L., Bache, F., Rabineau, M., Nouzé, H., Klingelhoefer, F., Contrucci, I., Labails, C., 2009. Brasilian and Angolan Passive Margins: the kinematic constraints. Tectonophysics 468, 98-112. 
Aslanian, D., Moulin, M., 2012. Paleogeographic consequences of conservational models in the South Atlantic Ocean. Geol. Society London Spec. Publ. 369, doi 10.1144/SP369.5.

Aslanian, D., Moulin, M., Rabineau, M., Afilhado, A., Bache, F. Leroux, E., Klingelhoefer, F., Schnurle, P., Matias, L., Gorini, C., 2013. Passive Margin genesis: Towards a general model? Teh insight of the Gulf of Lion-Sardinia System, Extended Abstract, The CircumMediterranean basins and analogues ILP-Workshop, Marseilles.

Bache, F., Olivet, J.-L., Gorini, F., Rabineau, M., Baztan, J., Aslanian, D., Suc, J.-P., 2009. Messinian Erosional And Salinity Crises: View From The Provence Basin (Gulf Of Lions, Western Mediterranean). Earth Planet. Sci. Lett. 286, 139-157.

Bache F., Olivet, J.-L., Gorini, C., Aslanian, D., Labails, C., Rabineau, M., 2010. Evolution of rifted continental margins: The case of the Gulf of Lions (Western Mediterranean Basin). Earth Planet. Res. Lett. 292, 3-4, 345-356.

Bertoni, C., Cartwright, J., Messinian evaporites and fluid flow, Marine and Petroleum Geology (2015), doi: 10.1016/j.marpetgeo.2015.02.003

Bjørlykke, Knut, , 2011. Petroleum Geoscience. From Sedimentary Environments to Rock Physics, Ed. Springer 508p.

Blanc, P.-L., 2002. The opening of the Plio-Quaternary Gibraltar Strait: assessing the size of a cataclysm. Geodin. Acta 15, 303-317.

Boillot, G., Féraud, G., Recq, M., Girardeau, J., 1989. "Undercrusting” by serpentinite beneath rifted margins: the examples of the west Galicia margin (Spain). Nature 341, 523-525.

Bott, M.H.P., 1971. Evolution of young continental margins and formation of shelf basin. Tectonophysics 11, 319-327.

Boussetta, S., Bassinot, F., Sabbatini, A., Caillon, N., Nouet, J., Kallel, N., ... \& Labeyrie, L. 2011. Diagenetic Mg-rich calcite in Mediterranean sediments: Quantification and impact 
on foraminiferal Mg/Ca thermometry. Marine Geology, 280(1), 195-204.

Braun,J., Thibaud Simon-Labric, Kendra E. Murray \& Peter W. Reiners, 2014. Topographic relief driven by variations in surface rock density. Nature Geoscience 7, 534-540, doi:10.1038/ngeo2171.

Brun, J.-P., Sokoutis, D., 2010. 45 m.y. of Aegean crust and mantle flow driven by trench retreat. Geology 38, 815-818.

Burov, E., Poliakov, A., 2001. Erosion and rheology controls on syn- and post-rift evolution: verifying old and new ideas using a fully coupled numerical model, J. Geophys. Res. 106, $16461-16481$.

Burov, E., The role of the gravitational instabilities, the density structure and the extension rate in the evolution of slow continental margins, Eds. G. D. Karner, G Manatschal, and L M Pinheiro , Geological Society of London Special Publications , SP 282 "Imaging, Mapping and Modelling Continental Lithosphere Extension and Breakup”, ISBN-13: 9781-86239-228-1, 488 pp., 2007.

Burov E., Part 1 Surficial and Deep Processes in Thrust Belts, Chapter 1: Coupled lithospheresurface processes in collision context, Eds: O. Lacombe, J. Lavé, F. Roure and J. Vergès, "Thrust belts and foreland basins: From fold kinematics to hydrocarbon systems", series " Frontiers in Earth Sciences“, Springer-Verlag, Berlin Heidelberg, p 1-40, ISBN-13: 978-3540-69425-0, 2007.

Burov E. and T. Gerya, Asymmetric three-dimensional topography over mantle plumes, NATURE, 513, 85-89, DOI: 10.1038/nature13703, 2014

Calignano, E., Sokoutis, D., Willingshofer, E., ...Strain localization at the margins of strong lithospheric domains : insights from analog modeling, Tectonics, 2015.

Camerlenghi, A., Accettella, D., Costa, S., Lastras, G., Acosta, J., Canals, M.,Wardell, N., 2009. 
Morphogenesis of the SW Balearic continental slope and adjacent abyssal plain, western Mediterranean Sea. International Journal Earth Sciences 98, 735-750.

Camerlenghi, A., Urgeles, R., and Fantoni, L., 2009. A database on submarine landslides of the Mediterranean Sea. In: Mosher, DC., Shipp, C., Moscardelli, L., Chaytor, J., Baxter, C., Lee, H., and Urgeles, R. (Eds.) Submarine Mass Movements and Their Consequences. Advances in Natural and Technological Hazards Research, Springer, 28:491-501

Carmenlenghi, A., Geletti, R., Chisari, D., Del Ben, A., Forlin, E., Mocnik, A., Romeo, R., Sauli, C., Wardell, N., 2012. Zgur F., Pre-salt fluids in the Mediterranean Basin. DS3F conference, Sitges.

Camerlenghi, Angelo, Vanni Aloisi, Johanna Lofi, Christian Hu bscher, Gert deLange, Rachel Flecker, Daniel Garcia-Castellanos, Christian Gorini, Zohar Gvirtzman, Wout Krijgsman, Stefano Lugli, Yizhaq Makowsky, Vinicio Manzi, Terry McGenity, Giuliana Panieri, Marina Rabineau, Marco Roveri, Francisco Javier Sierro, and Nicolas Waldmann, 2014 "Uncovering a Salt Giant », IODP multi-phase drilling project (MDP857), 31p.

Cande, S., Raymond, C., Stock, J. \& Haxby, W., 1995. Geophysics of the pitman fracture-zone and pacific-antarctic plate motions during the cenozoic, Science, Vol. 270, Issue 5238, 947 953, DOI: $10.1126 /$ science.270.5238.947

CIESM, 2008, The Messinian Salinity Crisis from mega-deposits to microbiology - A consensus report: CIESM Workshop Monographs, v. 33, p. 168.

Clauzon, G., 1973. The Eustatic Hypothesis And The Pre-Pliocene Cutting Of The Rhône Valley. In: Ryan, W.B.F., Hsü, K.J. et al. (Eds.), Leg 13. Initial Reports Of Deep Sea Drilling Project, Vol. 13, Washington, U.S. Government Printing Office, pp. 1251-1256. Cloetingh, S., Kooi, H., 1992. Tectonics and global change - inferences from Late Cenozoic subsidence and uplift patterns in the Atlantic/Mediterranean region. Terra Nova 4, 340- 
350.

Cloetingh, S., Bada, G., Matenco, L., Lankreijer, A., Horvath, F., Dinu, C., 2006. Modes of basin (de)formation, lithospheric strength and vertical motions in the PannonianCarpathian system: inferences from thermo-mechanical modelling. Geological Society, London, Memoirs 32, 207-221.

Cloetingh, S., Burov, E., Matenco, L., Beekman, F., Roure, F., Ziegler, P.A., 2013. The Moho in extensional tectonic settings: Insights from thermo-mechanical models. Tectonophysics $609,558-604$

Cloetingh, S., Ziegler et al., 2007. TOPO-EUROPE: The geoscience of coupled deep Earthsurface processes. Global Planet. Change 58(1-4), 1-118.

Cloetingh, S., Willett, S., 2013. TOPO-EUROPE: Understanding of the coupling between the deep Earth and continental topography. Tectonophysics 602, 1-14.

Crespo-Blanc, A., Frizon de Lamotte, D., 2006. Structural Evolution of the External Zones Derived from the Flysch Trough and the South Iberian and Maghrebian Paleomargins around the Gibraltar Arc: A Comparative Study. Bulletin de la Société Géologique de France, 177, 267-282.

Di Stefano, Agata; Foresi, Luca Maria; Lirer, Fabrizio; et al., 2008. Calcareous plankton high resolution bio-magnetostratigraphy for the Langhian of the Mediterranean area . RIVISTA ITALIANA DI PALEONTOLOGIA E STRATIGRAFIA Volume: 114 Issue: 1 Pages: $51-76$.

Droz, L., T. Dos Reis, M. Rabineau, S. Berné, G. Bellaiche, 2006 : Quaternary turbidite systems on the northern margin of the Balearic Basin (Gulf of Lions, Western Mediterranean): a synthesis, Geo-Marine Letters, December, 2006, Vol. 26, Issue 6, pp.347359. 
Eagle, R., Eiler, J., Tripati, A., Ries, J., Freitas, P., Hiebenthal, C., Wanamaker Jr., A., Taviani, M., Elliot, M., Richardson, C., Marenssi, S., Nakamura, K., Ramirez, P., Roy, K., 2013, The influence of temperature and seawater carbonate saturation state on $13 \mathrm{C}-18 \mathrm{O}$ bond ordering in bivalve mollusks, Biogeosciences, 10, 4591-4606.

Estrada, F., G. Ercilla, C. Gorini, B. Alonso, J.T. Vázquez, D. Garcia-Castellanos, C. Juan, A. Maldonado, A. Ammar, M. Elabbassi, 2011. Impact of pulsed Atlantic water inflow into the Alboran Basin at the time of the Zanclean flooding. Geo-Marine Lett., 1-16. doi: $10.1007 / \mathrm{s} 00367-011-0249-8$.

Eggenkamp, H.G.M., Kreulen, R., Koster Van Groos, A.F., 1995. Chlorine stable isotope fractionation in evaporite. Geochim. Cosmochim. Acta 59, 5169-5175.

Ellis, D.V., Well logging for Earth scientists, 1987. Elsevier, pp. 692.

Faccenna, C., Piromallo, C., Crespo-Blanc, A., Jolivet, L., Rosetti, F., 2004. Lateral slab deformation and the origin of the western Mediterranean arcs. Tectonics 23, TC1012, doi: $1010.1029 / 2002 T C 001488$.

Ferguson, J. E., Henderson, G. M., Kucera, M., \& Rickaby, R. E. M. (2008). Systematic change of foraminiferal $\mathrm{Mg} / \mathrm{Ca}$ ratios across a strong salinity gradient. Earth and Planetary Science Letters, 265(1), 153-166.

Flecker, R., de Villiers, S, Ellam, R.M, 2002. Modelling the effect of evaporation on the salinitySr-87/Sr-86 relationship in modern and ancient marginal-marine systems: the Mediterranean Messinian Salinity Crisis. Earth Planet. Sci. Lett. 203(1), 221-233.

Flecker, R., Ellam, R.M., 2006. Identifying Late Miocene episodes of connection and isolation in the Mediterranean-Paratethyan realm using Sr isotopes. Sediment. Geol. 188, 189-203.

Flores, JA; Sierro, FJ; Filippelli, GM; et al. Surface water dynamics and phytoplankton communities during deposition of cyclic late Messinian sapropel sequences in the western 
Mediterranean MARINE MICROPALEONTOLOGY Volume: 56 Issue: 1-2 Pages:

50-79 Published: JUL 2005.

Fry, J.C., R.J. Parkes, B.A. Cragg, A.J. Weightman, and G. Webster. 2008. Prokaryotic biodiversity and activity in the deep subseafloor biosphere. FEMS Microbiology Ecology 66: $181-196$

Gailler, A., Klingelhoefer, F., Olivet, J.-L., Aslanian, D., Afilhado, A., Bache, F., Beslier, M.-O., Cosquer, E., Deschamp, A., Droz, L., Gorini, C., Moulin, M., Nouzé, H., Oudet, J., Pascucci, V., Perrot, J., Rabineau, M., Réhault, J.-P., Allano, L., Bégot, J., Crozon, J., Fernagu, P., Labahn, E., Pelleau, P., Théreau., E., 2009. Crustal structure of a young margin pair: New results across the Liguro-Provencal Basin from wide-angle seismic tomography. Earth Planet. Sci. Lett. 286, 333-345.

Garcia-Castellanos D., Estrada F., Jiménez-Munt I., Gorini C., Fernàndez M., Vergés J., De Vicente R. (2009). Catastrophic flood of the Mediterranean after the Messinian Crisis. Nature, 462, 778-781, doi:10.1038/nature 08555, Supplementary Information : www.nature.com/nature

Garcia-Castellanos, D., Villaseñor, A., 2011. Messinian salinity crisis regulated by competing tectonics and erosion at the Gibraltar arc. Nature 480, 359-363.

Géli,L., H. Bougault, D. Aslanian \& A. Briais, L. Dosso, J. Etoubleau, J.-P. Le-Formal, M. Maia, H. Ondréas, J.-L. Olivet, C. Richardson, K. Sayanagi, N. Seama, A. Shah, I. Vlastelic, M. Yamamoto, Evolution of the Pacific-Antarctic Ridge south of the Udintsev fracture zone, Science, 278, 5341, Pages 1281-1284, 1997.

Gorini, C., 1993. Géodynamique d'une Marge Passive: Le Golfe Du Lion (Méditerranée Occidentale) (PhD Thesis). Univ. Paul Sabatier, Toulouse, p. 256.

Gorini, C., Montadert, L., Rabineau, M., New imaging of the salinity crisis: Dual Messinian 
lowstand megasequences recorded in the deep basin of both the eastern and western Mediterranean, Marine and Petroleum Geology (2015), doi: 10.1016/j.marpetgeo.2015.01.009.

Grevemeyer I, Kopf AJ, Fekete N, Kaul N, Villinger HW, Heesemann M, Wallmann K, Spieß V, Gennerich HH, Muller M, Weinreb W (2004) Fluid flow through active mud dome Mound Culebra offshore Nicoya Peninsula, Costa Rica: evidence from heat flow surveying. Mar Geol 207:145-157.

Hearst J.R., Nelson P.H. (1985). Well Logging for Physical Properties, McGraw-Hill, New York, pp. 570.

Hodell, D.A., Turchyn, A.V., Wiseman, C.J., Escobar, J., Curtis, J.H., Brenner, M., Gilli, A., Mueller, A.D., Anselmetti, F., Ariztegui, D., and Brown, E.T., 2012, Late glacial temperature and precipitation changes in the lowland Neotropics by tandem measurement of $\mathrm{d} 18 \mathrm{O}$ in biogenic carbonate and gypsum hydration water: Geochim. Cosmochim. Acta, v. 77, p. $352-368$.

Hoogakker, B. A., Klinkhammer, G. P., Elderfield, H., Rohling, E. J., \& Hayward, C. (2009). $\mathrm{Mg} / \mathrm{Ca}$ paleothermometry in high salinity environments. Earth and Planetary Science Letters, 284(3), 583-589.

Hsü, K.J., Ryan, W.B.F., Cita, M.B., 1973. Late Miocene Desiccation of The Mediterranean. Nature 242, 240-244.

Huismans, R.S., Beaumont, C., 2011. Depth-dependent extension, two-stage breakup and cratonic underplating at rifted margins. Nature 473, 74-78.

Jolivet, L., Faccenna, C., 2000. Mediterranean extension and the Africa-Eurasia collision Tectonics, Volume: 19 Issue: 6 Pages: 1095-1106. 
Jones, N., 2014. Global seismic network takes to the seas: Two systems could plug the oceansized gap in earthquake detection. Nature 507, 151.

Kastens, K.A., Mascle, J., Auroux, C., et al., 1987. Proc. ODP, Init. Repts., 107: College Station, TX (Ocean Drilling Program). doi:10.2973/odp.proc.ir.107.1987

Khademi, H., Mermut, A.R., and Krouse, H.R., 1997, Isotopic composition of hydration water in Selected landforms from central Iran: Chemical Geology, v. 138, p. 245-255.

Koptev, A., Calais, E., Burov, E., and S. Leroy, Dual continental rift systems generated by plume-lithosphere interaction, NATURE Geoscience, DOI: 10.1038/NGEO2401, 2015

Kooi, H., Cloetingh, S., Burrus, J., 1992. Lithospheric necking and regional isostasy at extensional basins, 1, Subsidence and gravity modelling with an application to the Gulf of Lions Margin (SE France). Journal of Geophysical Research 97, 17553-17572.

Krijgsman, W; Hilgen, FJ; Raffi, I; et al. 1999. Chronology, causes and progression of the Messinian salinity crisis, NATURE Volume: 400 Issue: 6745 Pages: 652-655.

Krijgsman, Wout; Leewis, Marianne E.; Garces, Miguel; et al., 2006. Tectonic control for evaporite formation in the Eastern Betics (Tortonian; Spain). SEDIMENTARYGEOLOGY Volume: 188 Special Issue: SI Pages: 155-170.

Krijgsman, W., Stoica, M., Vasiliev, I., Popov, V.V., 2010. Rise and fall of the Paratethys Sea during the Messinian Salinity Crisis. Earth and Planetary Science Letters 290, 183-191.

Kuznir, N.J., Karner, G. D., 2007. Continental lithospheric thinning and breakup in response to upwelling divergent mantle flow: application to the Woodlark, Newfounland and Iberia margins. Geol. Soc. London Spec. Publ. 282, 389-419.

Labails, C., Olivet, Jean-Louis, and DAKHLA group, 2009. Crustal structure of the SW Moroccan margin from wide-angle and reflection seismic data (the Dakhla experiment). Part B - The tectonic heritage. Tectonophysics, Volume 468, Issues 1-4, 1 April 2009, 
Pages 83-97.

Lafuerza, S., Sultan, N., Canals M., Lastras G., Cattaneo A., Frigola J., Costa S., Berndt C. (2012). Failure mechanisms of Ana Slide from geotechnical evidence, Eivissa Channel, Western Mediterranean Sea. Marine Geology, 307-310, 1 21.http://dx.doi.org/10.1016/j.margeo.2012.02.010.

Lanaja, J. M. 1987. Contribucion de la exploracion petrolofera al conocimiento de la geologica de Espagna, instituto Geologico y Minero de España, 1987, 465 p.

Lavier, L., Manatschal, G., 2006. A mechanism to thin the continental lithosphere at magmapoor margins. Nature 440, 324-328.

Leever, K.A., Matenco, L., Rabagia, T., Cloetingh, S., Krijgsman, W., Stoica, M., 2010. Messinian sea level fall in the Dacic Basin (Eastern Paratethys): palaeogeographical implications from seismic sequence stratigraphy. Terra Nova 22, 12-17.

Leroux, E., 2012. QuantificationdesfluxsédimentairesetdelasubsidencedubassinProvençal (PhD Thesis). Sciences de la Terre, Univ. Brest, p. 455, http://www.ifremer.fr/docelec.

Leroux, E., Rabineau, M., Aslanian, D., Granjeon, D., Gorini, C., Droz, L. et al. Stratigraphic simulation on the shelf of the Gulf of Lion : testing subsidence rates and sea-level curves during Pliocene and Quaternary, 2014, Terra Nova, 26, 230-238.

Leroux, E., Aslanian, D. Rabineau, M., Moulin, M., Granjeon, D., Gorini, C., Droz, L., 2015. Sedimentary markers: a window into deep geodynamic processes. Terra Nova.

Leroux, E., M. Rabineau, D. Aslanian, C. Gorini, F. Bache, M. Moulin, Pellen, R., Granjeon, D., J-L. Rubino, in press. Post-rift evolution of the Gulf of Lion margin tested by stratigraphic modelling, Bull. Soc. Géol. France, ILP special Volume.

Lirer, F; Iaccarino, S. Integrated stratigraphy (cyclostratigraphy and biochronology) of late Middle Miocene deposits in the Mediterranean area and comparison with the North and 
Equatorial Atlantic Oceans: synthesis of the major results TERRA NOVA Volume: 17 Issue: 4 Pages: 338-349 Published: AUG 2005.

Lofi, J., Sage, F., Déverchère, J., Loncke, L., Maillard, A., Gaullier, V., Thinon, I., Gillet, H., Guennoc, P., Gorini, C., 2011. Refining our knowledge of the Messinian salinity crisis records in the offshore domain through multi-site seismic analysis. Bull. Soc. Géol. France $182,163-180$.

Loget, N., Van Den Driessche, J., Davy, P., 2005. How did the Messinian Salinity Crisis end? Terra Nova 17, 414-419.

Loget, N., Moscariello, A., Matenco, L., Suc, J-P. Coring a foreland basin: Upper Rhône Valley Events (CURVE). Impressive sedimentary archive of global climate-eustasy and Mediterranean changes (Alps orogenesis, Messinian Salinity Crisis), hydrogeological perspective, ICDP Workshop proposal, 23p.

Lucazeau, F., Le Douaran, S., 1985. The blanketting effect of sediments in basins formed by extension : a numerical model. application to the gulf of lion and the viking graben. Earth Planet. Sci. Lett. 74 (1), 92-102.

Lucazeau, F., Leroy. S., Rolandone, F., D’Acremont, E., Watremer, L., Bonneville, A., Goutorbe, B., Düsünur, D., 2010. Heat-flow and hydrothermal circulation at the oceancontinent transition of the eastern Gulf of Aden. Earth Planet. Sci. Lett. 295, 554-570.

Lugli, S., Manzi, V., Roveri, M., 2010. The primary Gypsum in the Mediterranean: A new fades interpretation for the first stage of the Messinian salinity crisis. Palaeogeogr., Paleoclimatol., Paleoecol. 297(1), 83-99.

Maignien, L. R. John Parkes, Barry Cragg, Helge Niemann, Katrin Knittel, Stephanie Coulon, Andrey Akhmetzhanov and Nico Boon, 2013. Anaerobic oxidation of methane in hypersaline cold seep sediments, FEMS Microbiology Ecology, 83, p. 214-231 
Marillier, F., Tomassino, A., Patriat, P., Pinet, B., 1988. Deep structure of the Aquitaine Shelf; constraints from expanding spread profiles on the ECORS Bay of Biscay transect. Mar. Petrol. Geol. 5(1), 65-74.

Matenco, L., Radivojević, D., 2012. On the formation and evolution of the Pannonian Basin: Constraints derived from the structure of the junction area between the Carpathians and Dinarides. Tectonics 31, TC6007.

Matenco, L., Andriessen, P., 2013. Quantifying the mass transfer from mountain ranges to deposition in sedimentary basins: Source to sink studies in the Danube Basin-Black Sea system. Global and Planetary Change 103, 1-18.

Maury V., Etchecopar A., Pezard P.A. (1999). Borehole rupture modes and their relationship to the in situ state of stress; unsolved questions. Proceedings of the SPWLA $40^{\text {th }}$ Ann. Symp. (Oslo, Norway).

McKenzie. D., 1978. Some remarks on the development of sedimentary basins. Earth Planet. Sci. Lett. 40(1), 25-32.

Moulin, M., Aslanian, D., Olivet, J-L., Contrucci, I., Matias, L., Géli, L., Klingelhoefer, F., Nouzé, H., Réhault, J.P., Unternehr, P., 2005. Geological constraints on the evolution of the Angolan margin based on reflection and refraction seismic data (ZaïAngo project). Geophys. Journ. Intern. 162, 793-810.

Moulin, M., Klingelhoefer, F., Afilhado, A., Aslanian, D., Schnurle, P., Nouzé, H., Rabineau, M., Beslier, M.O., Feld, A., in press. Deep crustal structure across an young passive margin from wide-angle and reflection seismic data (The SARDINIA Experiment) - I. Gulf of Lion’s margin. Bull. Soc. Géol. France Spec Vol.

Munteanu, I., Matenco, L., Dinu, C., Cloetingh, S., 2011. Kinematics of back-arc inversion of the Western Black Sea Basin. Tectonics 30, TC5004. 
Munteanu, I., Matenco, L., Dinu, C., Cloetingh, S., 2012. Effects of large sea-level variations in connected basins: the Dacian-Black Sea system of the Eastern Paratethys. Basin Research 24, 583-597.

Munteanu, I., Willingshofer, E., Sokoutis, D., Matenco, L., Dinu, C., Cloetingh, S., 2013. Transfer of deformation in back-arc basins with a laterally variable rheology: Constraints from analogue modelling of the Balkanides-Western Black Sea inversion. Tectonophysics $602,223-236$.

Munteanu, I., Willingshofer, E., Matenco, L., Sokoutis, D., Cloetingh, S., 2014. Far-field contractional polarity changes in models and nature. Earth and Planetary Science Letters $395,101-115$.

Ní Fhlaithearta, S., Reichart, G. J., Jorissen, F. J., Fontanier, C., Rohling, E. J., Thomson, J., \& De Lange, G. J., 2010. Reconstructing the seafloor environment during sapropel formation using benthic foraminiferal trace metals, stable isotopes, and sediment composition. Paleoceanography, 25(4).

Ochoa, Diana; Sierro, Francisco J.; Lofi, Johanna; Maillard, Agnès; Flores, Jose-Abel; Suárez, Mercedes. Onset of the Messinian Salinity Crisis: First Mediterranean offshore evidence, submitted, EPSL.

Olivet, J.-L., 1996. La Cinématique de la plaque Ibérique. Bull. Centres Rech. Explor.-Prod. Elf-Aquitaine 20, 131-195.

Ondréas, H., Aslanian, D., Géli, L., Olivet, J.-L. and Briais, A. ,2001. Variations in axial morphology, segmentation, and seafloor roughness along the Pacific-Antarctic Ridge between $56^{\circ} \mathrm{S}$ and $66^{\circ}$ S, Journal of Geophysical Research, Vol. 106, No B5, Pages 8,5218,543 . 
Pascal, G.P., Mauffret, A., Patriat, P., 1993. The ocean-continent boundary in the Gulf of Lion from analysis of expanding spread profiles and gravity modelling. Geophys. Journ. Intern. $113,701-726$.

Péron-Pindivic, G., Manatschal, G., 2009. The final riftng evolution at deep magma-poor passive margins from Iberia-Newfounland: a new point of view. Int. J. Earth Sci. doi:10.1007/s00531-008-0337-9.

Pezard P.A., Lovell M.A. and the Scientific Party of ODP Leg 126 (1990). Electrical Images of the Earth Crust. EOS, 71/20: 709-710.

Pezard P.A., Lovell M.A., Hiscott R.N. (1992). Downhole Electrical Images in Volcaniclastic Sequences from the Izu-Bonin Forearc Basin, Western Pacific. In TAYLOR B., FUJIOKA K., et al., Proc. ODP, Sci. Results (Part B), 126: 603-626.

Poort J, Klerkx J (2004) Absence of a regional surface thermal high in the Baikal Rift; new insights from detailed contouring of heat flow anomalies. Tectonophysics 383:217-241.

Popov, S.V., Shcherba, I.G., Ilyina, L.B., Nevesskaya, L.A., Paramonova, N.P., Khondkarian, S.O., Magyar, I., 2006. Late Miocene to Pliocene palaeogeography of the Paratethys and its relation to the Mediterranean. Palaeogeography, Palaeoclimatology, Palaeoecology 238, 91 106

Rabineau, M., Berné,S., Aslanian, D., Olivet J-L., Joseph, P, Guillocheau, F, Bourillet, J-F., Ledrezen, E., Granjeon, D., 2005 : Sedimentary sequences in the Gulf of Lions : a record of 100,000 years climatic cycles, Marine and Petroleum Geology, 22, p. 775-804)

Rabineau, M., S. Berné, J-L Olivet, D. Aslanian, P. Joseph, F. Guillocheau, 2006 : Paleosea levels reconsidered from direct observation of paleoshoreline position during Glacial Maxima (for the last 500000 yr) (Earth and Planetary Science Letters, Volume: 252 Issue: 1-2 Pages: 119-137 DOI: 10.1016/j.epsl.2006.09.033 Published: NOV 302006 
Rabineau, M., Leroux, E., Aslanian,D., Bache, F., Gorini, C., Moulin, M., Molliex, S., Droz, L., Dos Reis, T., Rubino, J.-L., Olivet, .J.-L., Guillocheau F., 2014. Quantification of PlioceneQuaternary Subsidence and isostatic readjustment related to the Messinian Erosional and Salinity Crisis. Earth Planet. Sci. Lett. 388, 353-366.

Renoux, P. (1991) Well log and seismic response of Permo-Triassic evaporites, ZechsteinMuschelkalk-Keuper. In: Spencer, A.M. (ed.). Generation, accumulation and production of Europe's hydrocarbons, Special Publication of the European Association of Petroleum Geoscientists, No. 1., Springer -Verlag, Berlin, p. 229-240.

Réhault, J.-P., Boillot, G., Mauffret, A., 1984. The western Mediterranean Basin geological evolution. Mar. Geol. 55, 447-477.

Reston, T.J., 2010. The opening of the central segment of the South Atlantic: symmetry and the extension discrepancy. Petrol. Geosci. 16, 199-206.

Rohling, E. J., \& De Rijk, S. (1999). Holocene Climate Optimum and Last Glacial Maximum in the Mediterranean: the marine oxygen isotope record.Marine Geology, 153(1), 57-75.

Siam, R., G.A. Mustafa, H. Sharaf, A. Moustafa, A.R. Ramadan, et al. 2012. Unique Prokaryotic Consortia in Geochemically Distinct Sediments from Red Sea Atlantis II and Discovery Deep Brine Pools. PLoS ONE 7(8): e42872.

Sibuet, J.-C., Tucholke, B., 2012. The Geodynamic Province of Transitional Lithosphere Adjacent to Magma-Poor Continental Margins. Geol. Soc. London Spec. Publ. 369, 429_ 452.

Sierro, FJ; Ledesma, S; Flores, JA; et al. Sonic and gamma-ray astrochronology: Cycle to cycle calibration of Atlantic climatic records to Mediterranean sapropels and astronomical oscillations_GEOLOGY Volume: 28 Issue: 8 Pages: 695-698 Published: AUG 2000 
Sierro, FJ; Hilgen, FJ; Krijgsman, W; et al., 2001 The Abad composite (SE Spain): a Messinian reference section for the Mediterranean and the APTS. PALAEOGEOGRAPHY PALAEOCLIMATOLOGY PALAEOECOLOGY Volume: 168 Issue: 1-2 Pages: 141169 Published: APR 12001

Sprovieri, M; Barbieri, M; Bellanca, A; et al. Astronomical tuning of the Tortonian Sr-87/Sr-86 curve in the Mediterranean basin , TERRA NOVA Volume: 15 Issue: 1 Pages: 29-35 Published: FEB 2003.

Tang, J., Dietzel, M., Fernandez, A., Tripati, A., Rosenheim, B., 2014, Evaluation of kinetic effects on clumped isotope fractionation during inorganic calcite precipitation, Geochimica et Cosmochimica Acta, 134, 120-136.

ter Borgh, M., Radivojević, D., Matenco, L., 2014. Constraining forcing factors and relative sealevel fluctuations in semi-enclosed basins: the Late Neogene demise of Lake Pannon. Basin Research, in press.

Tesauro, M., Burov, E.B., Kaban, M.K., Cloetingh, S.A.P.L., 2011. Ductile crustal flow in Europe's lithosphere. Earth and Planetary Science Letters 312, 254-265.

Teske, A., and K.B. Sørensen. 2008. Uncultured Archaea in deep marine subsurface sediments: have we caught them all? The ISME Journal 2:3--18.

Thybo, H., Nielsen, C.A., 2009. Magma-compensated crustal thinning in continental rift zones. Nature 457, 873-876.

Torné, M., Pascal, G., Buhl, P., Watts, A.B., Mauffret, A., 1992. Crustal and velocity structure of the Valencia trough (western Mediterranean), Part I. A combined refraction/ wide-angle reflection and near-vertical reflection study. Tectonophysics 203, 1-20.

Tripati, A., Sahany, S., Pittman, D., Eagle, R., Neelin, D., Mitchell, J., Beaufort, L., 2014, Modern and glacial tropical snowlines controlled by sea surface temperature and 
atmospheric mixing, Nature Geoscience, 7, 205-209.

Tripati, A., Thiagarajan, N., Eagle, R., Gagnon, A., Bauch, H., Eiler, J., 2010, Apparent equilibrium 13C-18O isotope signatures and 'clumped isotope' thermometry in foraminifera and coccoliths, Geochimica et Cosmochimica Acta, 74, 5697-5717.

Turco, E., Hilgen, F. J., Lourens, L. J., Shackleton, N. J., \& Zachariasse, W. J. (2001). Punctuated evolution of global climate cooling during the Late Middle to Early Late Miocene: High-resolution planktonic foraminiferal and oxygen isotope records from the Mediterranean. Paleoceanography, 16(4), 405-423.

Unternehr, P., Péron-Pindivic, G., Manatschal, G., Sutra, E., 2010. Hyper-extended crust in the South Atlantic: in search of a model. Petrol. Geosci. 16, 207-215.

Van Den Driessche, A.E.S., García-Ruíz, J.M., Tsukamoto, K., Patiño-Lopez, L.D., Satoh, H., 2011. Ultraslow growth rates of giant gypsum crystals. Proc. Natl. Acad. Sci., doi:10.1073/pnas.1105233108.

Vengosh, A., Starinsky, A., Kolodny, Y., Chivas, A.R., M. Raab, M., 1992. Boron isotope variations during fractional evaporation of sea water: New constraints on the marine vs. non marine debate. Geology 20, 799-802.

Watremez L., Burov E., d'Acremont E., Leroy S., Huet B., Le Pourhiet L., Bellahsen N., Buoyancy and localizing properties of continental mantle lithosphere: Insights from thermomechanical models of the eastern Gulf of Aden, Geochemistry, Geophysics, Geosystems, 10.1002/ggge.20179, ISSN: 15252027, 2013

Wernicke, B., 1985. Uniform-sense normal simple shear of the continental lithosphere. Can. Journal of Earth Sci. 22, 22.108-22.125.

Williams, T., Kroon, D., Spezzaferri, S., 2002. Middle and Upper Miocene cyclostratigraphy of downhole logs and short- to long-term astronomical cycles in carbonate production of the 
Great Bahama Bank, Marine Geology 185 (2002) 75-93.

Yang, W., Spencer, R.J., Krouse, H.R., Lowenstein. T., and E. Casas, 1995, Stable isotopes of lake and fluid inclusion brines, Dabusun Lake, Qaidam Basin, western China: Hydrology and paleoclimatology in arid environments; Palaeogeography, Palaeoclimatology, Palaeoecology, v. 117, p. 279-290.

Zemanek, J.R., Glenn, E.E., Norton, L.J., Caldwell, R.L., 1970. Formation evaluation by inspection with the borehole televiewer. Geophysics, 35 (2), 254 - 269. 
NEW FIGURES and captions

Figure Captions :

Figure 1 - Location map (modified from Bache et al., 2009). The Gulf of Lion is located in the green square. The location of the synthetic line A-A' showed in Figure 2 is in red.

Figure 2 - Composite line drawing cross-section showing the markers of the MSC (modified from Lofi, et al., 2011; and the drilling strategy of the MDP "Uncovering a Salt Giant" (Camerlenghi et al., 2014). GOLD represents the Deep basin site (Target A). See approximate position of A-A' in Figure 1. The blue line represents present-day sea-level.

Plate 1 - Top: Location of the Sardinia profiles (red lines in the top figure) and the GOLD project in the Gulf of Lion. The NW-SE profile was extended onland (red and yellow circles). The grey lines represent the limits of the different crustal domains (see the text for more details). After Moulin et al., submitted. Bottom: GOLD drilling position on the two Sardinia seismic profiles. The multi-channel seismic reflection data was acquired using a $4.5 \mathrm{~km}$ long, 360 trace digital streamer and a tuned airgun array of $8260 \mathrm{in} 3$. The blue line on seismic profile represents the sea-floor.

Plate 2 - Summary of addressed questions and sampling strategy of the GOLD project

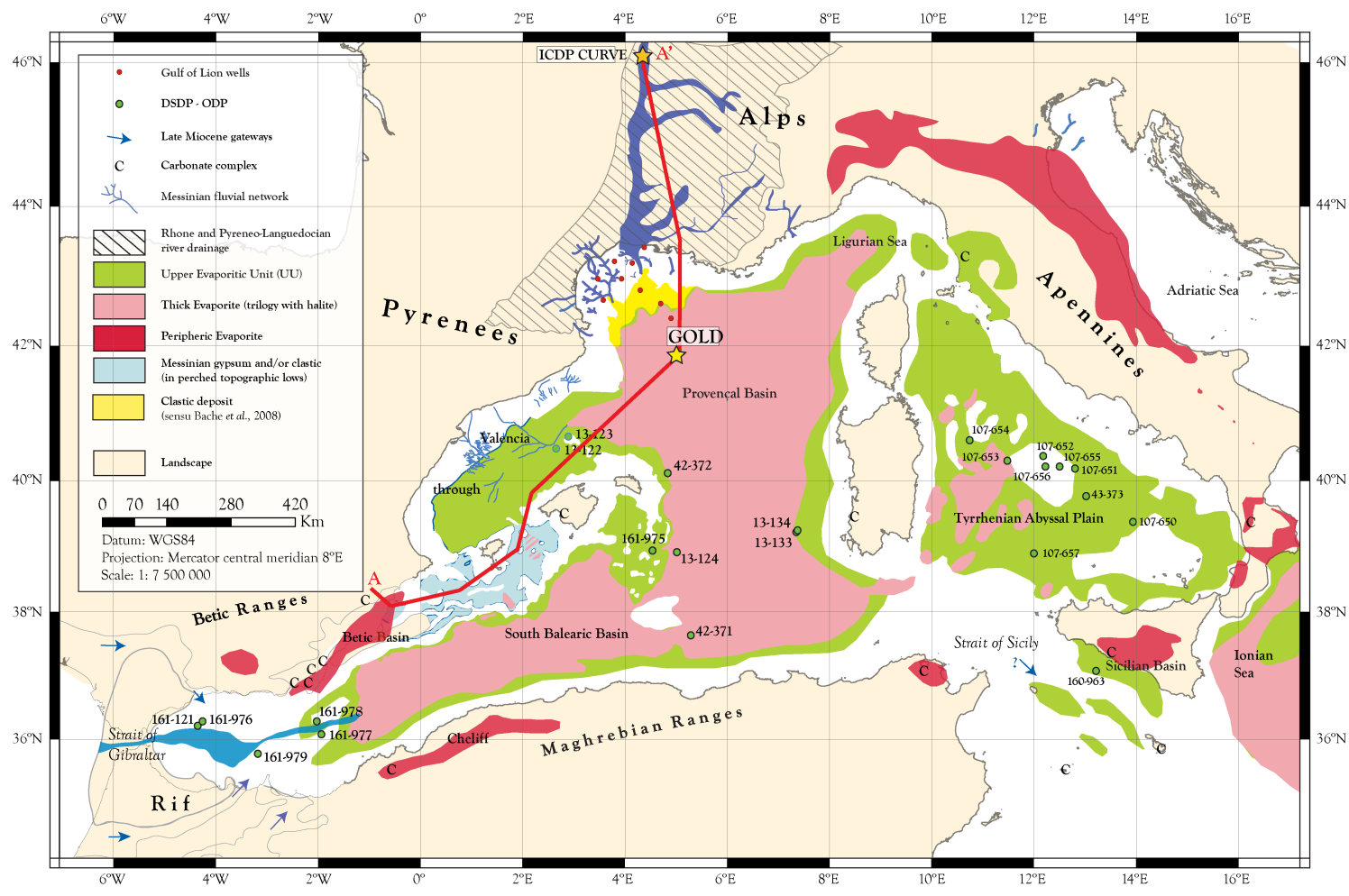




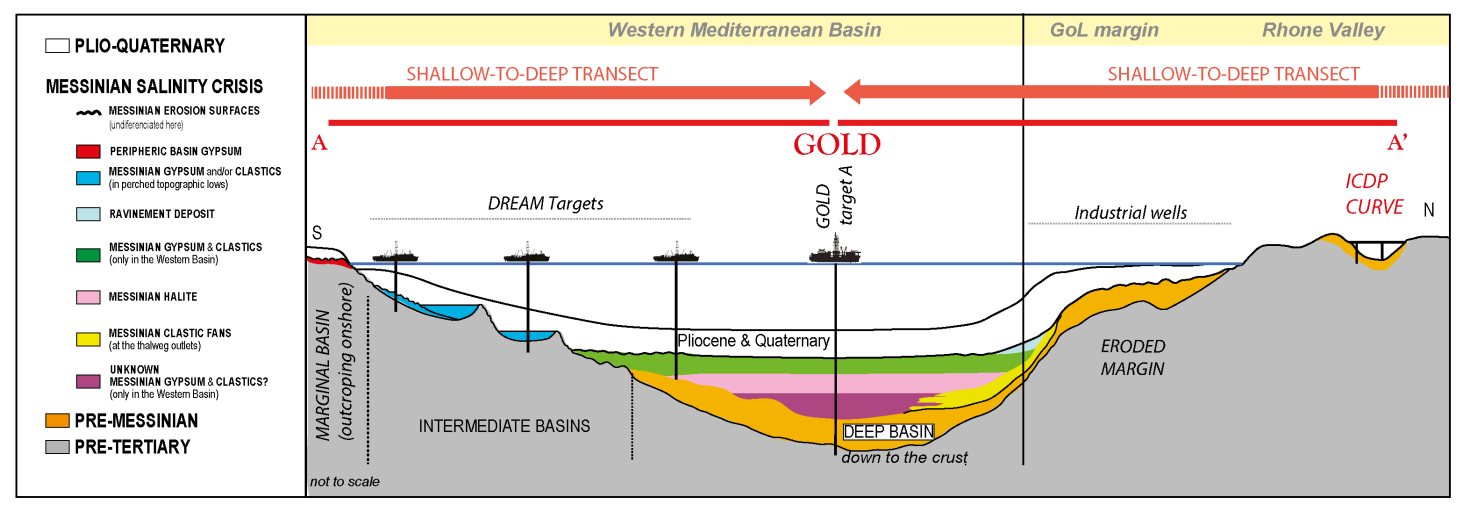

Figure 2 - Composite line drawing cross-section showing the markers of the MSC (modified from Lofi, et al., 2011;

and the drilling strategy of the MDP "Uncovering a Salt Giant" (Camerlenghi et al., 2014).

GOLD represents the Deep basin site (Target A). See approximate position of A-A' in Figure 1. 


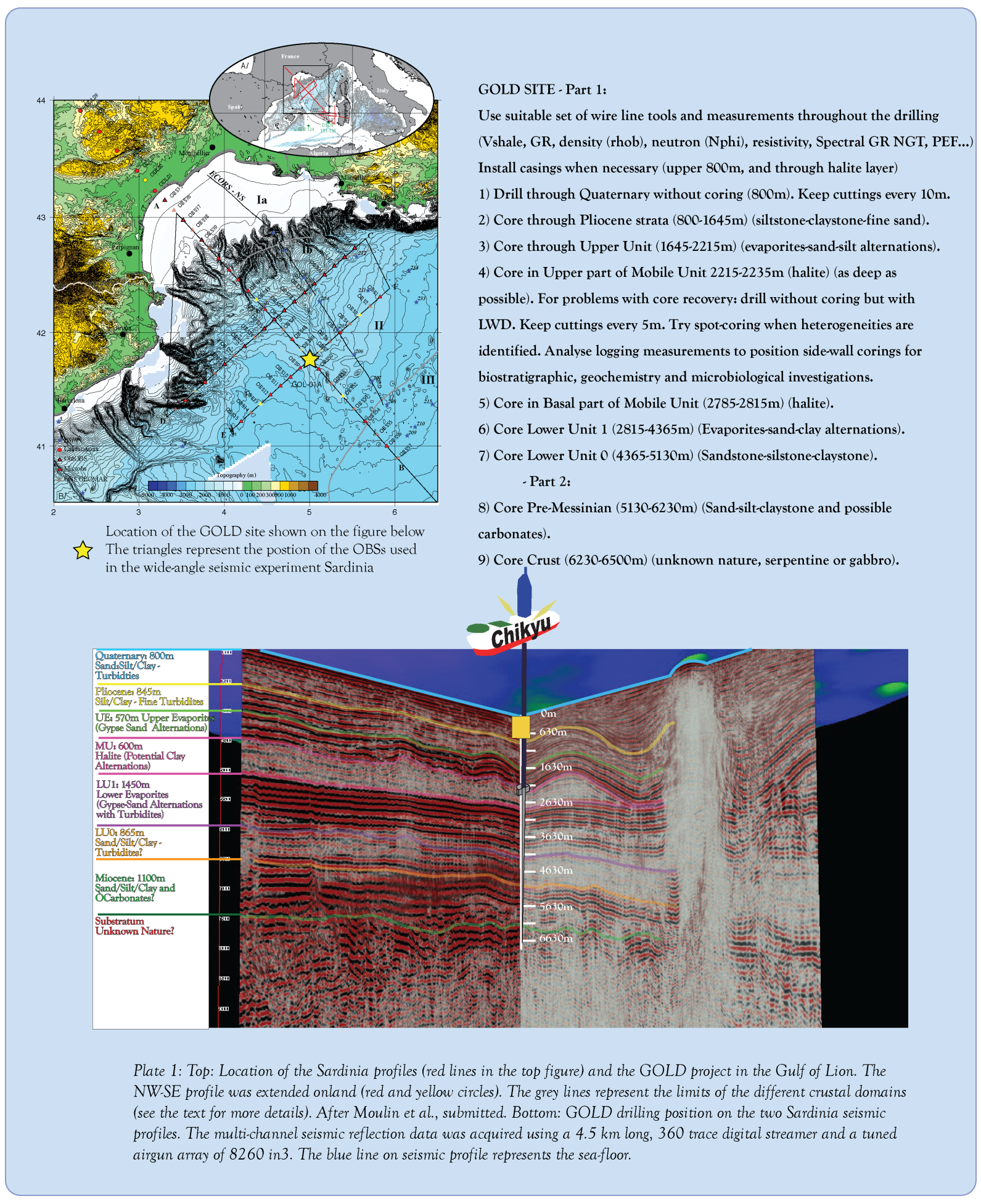




\section{Addressed questions}

What is the nature, age, and paleobathymetry of sedimentary deposits

When did the margin start to subside?

What are the thermomechanical properties and spatio-temporal variations in crustal lithosphere structure?

How did major rivers behave during the MSC? (erosion, karstification, supply, transport, landscape. relief evolution, mass transfer)

What was the effect of the Messinian event on the subsidence history (water, salt, and sediment masstransfers)? What are the consequences for thermo-mechanic models?

What is the history of water exchange between the Mediterranean Sea and the North Atlantic?

\section{$>$ Sampling strategy/data collection}

\section{Understanding connections between deep earth and surface processes}

$>$ multiscale seismic imaging of basin fill and crustal and upper mantle structure

$>$ drilling monitoring and casing and set of wireline logging: geophysical and geochemical properties

$>$ coring of the different MSC lithological units (Pliocene, UU, LU1, LU0) and potential spotcoring in halite (MU), coring of pre-Messinian units and crust material,

$>$ exhaustive study of core material, taking into account diagenetic history and leveraging sedimentary biostratigraphic (foraminifera, nannofossils, dinoflagellates, ostracodes, diatoms), palynological, sedimentological, and geochemical analyses (including the chemical composition of pore waters), along with physical, paleomagnetic, petrological, and stable isotope study of the crustal cores.

\section{Deep Biosphere 8 Deformation and fluid flow}

$>$ spot-coring of the different lithological units (every $\sim 100 \mathrm{~m}$ )

$>$ wireline logging of a set of geophysical and geochemical in situ properties

$>$ sampling of in situ formation fluids using wireline sampling tools

$>$ extensive microbiological, genomic, biogeochemical, geological, palaeoceanographical and geophysical analyses of the core.

Plate 2: Summary of addressed questions and sampling strategy of the GOLD project 